\title{
The Principal Visionair Leadership of Islamic Integrated Elementary School Baitul Jannah Bandar Lampung
}

\author{
Ninuk Endah Susanti *Sumadi, Dedy Hermanto Karwan \\ Magister Manajemen Pendidikan, FKIP Universitas Lampung, J1. Prof. Dr. Soemantri Brojonegoro No 1 \\ Bandar Lampung
}

\begin{abstract}
Visionary leadership is the leadership of the principal who can be an alternative model of leadership style of the principal to advance the institution he leads in the future by analyzing and describing how the principal creates, formulates, transforms, and implements the school's vision and mission in Integrated Islamic Primary Schools. This study was designed with a phenomenological qualitative method, the principal as the center of the informant, to complete the information needed by the assistant informant. The results of this study are that the Principal of SDIT is: 1) the head of the visionary school, 2) the Islamic Primary School implements teacher and student guidance to achieve the vision of the Integrated Islamic school mission, 3) This SDIT has good output for education, marked by effective school , 4) have a commitment to form student character in noble character, 5) have academic and non academic achievements, 6) output of students can be received in favorite junior high schools in Bandar Lampung or outside Bandar Lampung, 7) school characteristics
\end{abstract}

Keywords: visionary leadership, principal leadership.

DOI: $10.7176 / \mathrm{JEP} / 10-10-05$

Publication date: April $30^{\text {th }} 2019$

\section{Introduction}

Education in Indonesia along with the era development and the globalization is very rapid demanding an increase in the quality of education. The school aims to lay the foundation for intelligence, knowledge, personality, noble character, and skills to live independently and follow further education. School is a formal educational institutions whose role is to prepare the children to be able to enter the society in the future.

One of the national education goals formulated in government regulation number 32 of 2013 concerning Education National Standard (SNP) can run optimally, if schools are managed professionally in carrying out their functions as formal education institutions.

Based on Nurhidaya (2017), Fitrah (2017) and Rosyada (2013) that education is experiencing a variety of shocks and weakening of education so that need a large role of the principal and very decisive for the decline of education, and the role of the teacher is required to be responsible for the quality of processes and the results of learning.

The role of the Integrated Islamic School, wants to be better and more characteristi in a education changing, with the aim of realizing a school model that is able to integrate the knowledge of qauli and qauni into a unity in learning (Alaydroes, Fahmy et al., 2014: 5).

In reality not many principals know exactly what the goals are, the vision of their Integrated Islamic School (SIT) and how to realize that vision. In fact, not many principals really understand the meaning of the vision and mission of the Integrated Islamic School (SIT) they lead. In fact there are still several schools in formulating the vision, mission and objectives of the school is unclear, and not in accordance with existing conditions. The formulation of the school's vision and mission is still plagiarized and it does not describe the autonomy of school autonomy (Ade Irwana, 2015: 104).

The author will examine the appropriate leadership style to be used in leadership in SDIT as a means to improve, maintain quality so that the excellence of SIT will be maintained.

According to Bafadal (2016), Karweti (2010), Yuzrizal, (2014) and Yasen (2016), the success of principals' leadership can be seen from managerial skills in carrying out their duties, utilizing available resources, effectiveness of principals in formulating vision, mission, goals, and targets for learning success of students and programs, achieving school goals effectively and efficiently, and the leadership style of principals as a key for the development, student success and programs.

The principal according to Erfan (2017), Mulyasa (2013), Somad (2014), and Puspitasari (2017) that the principal is planning a vision and mission, formulating vision and mission, socializing the vision and mission, formulating the main strategy, being responsible for school, influence, guide others, provide direction to achieve certain goals for progress.

The author have reason in determining the location of the study based on the absence of research on leadership style, precisely the visionary leadership style of principals, in Integrated Islamic Elementary Schools that have the same type, based on a theory that has been explained above that the authors are interested in writing the step of Principals Leadership Visionary of Integrated Islamic Elementary School in Bandar Lampung. 


\section{Principals Leadership}

Leadership according to Stephen P. Robin (2006) and Makawimbang (2012) is someone who has the ability to influence others, motivating to communicate effectively, both individually and organizationally to carry out the goals and the object that will be achieved.

Principals leadership is very important for school effectiveness and a milestone in many economic growth, leadership in planning, implementing, and evaluating all the character education implementation.

Based on Sedarmayanti (2010) and Mulyasa (2013) James (2013) and Fitrah (2017: 39) principals' leadership is someone who is able to influence others, motivate to communicate effectively, both individually and organizationally, because school leadership is very important to be an effective school and the successful implementation of character education for learners, must formulate a vision, create a school atmosphere, instill leadership attitudes, improve learning, and manage all activities so that schools become productive, effective, independent, must be in accordance with the school's vision so that it has the function of creating qualified schools.

In accordance with Permendikbud number 15 of 2018 chapter VI paragraph 1, about the workload of teachers, principals, and supervisors, is explained that the main principal task, the principal workload is the full workload of the principal to carry out the main managerial tasks, the development, the entrepreneurship, and supervision of the teachers and staff education.

\section{Visionary Leadership}

Visionary leadership according to Mukti (2018) and Ibnu Nasir (2012), Sherly (2011), Wahyudi (2012), Diana (2003) is the leadership style of principals to advance the institutions they lead that have a clear vision and mission in the organization, intelligent in observing an event in the future, has a clear vision and mission vision, an intelligent leader in observing an event in the future, can arouse the spirit of its members, motivate it and built their imagination, make an organization more alive, through the commitment of all members of the organization, and also through the process of socialization, transformation, implementation of ideal ideas by the leadership of the organization, giving meaning in working and effort, direction, and the effort which carried out based on a clear vision towards visionary leadership, principals should have steps:

\section{Creating School Vision and Mission}

Leadership ability according to Robbins (2006) and Hidayah (2016) is to create and articulate a reality, trustworthy, and interesting about the future of the organization or the core of the organization that continues to grow and increase. This means that the school must be futuristic and not peddle something that has been stale or something that is not useful for the future because it is obsolete.

The stages of vision creation, according to Ani Kalayjian (2013), a visionary who is able to create a clear and directed vision through several stages, which are clear and directed through Trend Watching (predicting) and Envisioning (observation).

\section{Formulating School Vision and Mission}

The principal who is responsible tries to find out the school's vision. Ibrahim (2016) and Akdon (2006: 94) formulating a vision and mission is the ability of leaders to make clear planning so that the formulation of vision and mission will be reflected goals, inspirational, inspiring, managing, inviting others to change, moving to 'new place', able to inspire, motivate others to work more creatively.

The preparation of the vision and mission of the Elementary School education unit should pay attention to the juridical foundation of Law number 20 of 2003 concerning the National Education System, government regulation number 19 of 2005 concerning the National Education Standards which was amended to number 32 of 2013, Permendikbud number 22 in 2016 concerning the competence of primary and secondary education graduates, number 23 in 2016 concerning standard assessment, core competencies and basic competencies in 2018 number 37, and about the 2013 curriculum in number 35 of 2018.

The technique of formulating a vision is by reviewing the problems, both internally and externally by strengthening Strengths, Weakness, Opportunities, and Treats (SWOT), by analyzing the context of strengths, weaknesses, owned by schools, and seeing opportunities and threats that occur around the school. Criteria for good mission formulation characteristics as follows: 1) formulation in line with the vision of the unit organization / work unit, 2) clear formulation with straight forward language, 3) formulation describing the work or function that must be implemented, can be implemented in a certain period of time, and 4) allow for changes / adjustments to changes in vision. 
Technique of Vision Formulating

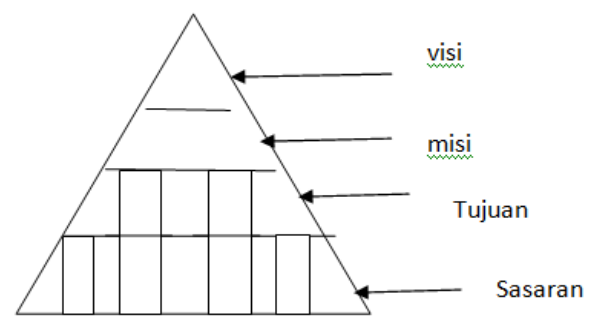

Figure 2.1: Describing of vision and mission to the object and target

Source: Forum Guru Nusantara (2016)

\section{Transforming School Vision and Mission}

Based on Hidayah (2015), Robbins (2012), Nanus (2010) above, concluded that leaders should be able to build trust in the school environment, the ability to explain, express the vision and mission, convey the school's vision and mission, develop an image, precisely according to school goals while collaborating with people to build, maintain, and develop the vision they embrace.

\section{Implementation of School Vision and Mission}

The success of schools depends on the school leadership and it is very important (Kurland, Peretz, \& HertzLazarowitz, 2010) (Leithwood \& Jantzi, 2005) (Leithwood and Riehl, 2003; Harris, 2005; Hallinger, 2003; Stewart, 2006).

Based on Nanus (2010) it can be concluded that visionary leaders have four roles in implementing their leadership, 1) direction setting (direction setter), 2) agent of change, 3) spokesperson, 4) coach, whereas in implementing more humanitarian program, guaranteeing students in various professional fields, preparing competent students, the education curriculum must be able to maintain harmony, longlife learning needs and internationalization of education, create productive education, as agents of change, direction determinants organization, a professional supervisor, displays the strength of knowledge, professional experience and education.

\section{METHOD}

The approach of this research is phenomenological qualitative. This approach is qualitatively chosen because the object of this research is the behavior or activity of several people. According to Moleong (2017:) qualitative research is the research that intends to understand the phenomenon of what is experienced by the subject of the researcher. Data is collected through interviews with informants and direct observations in the field, then analyzed inductively.

One of the forms of qualitative research that can indeed be used primarily to develop theories that are lifted from several similar research backgrounds, so that theories can be produced that can be transferred to a wider and more general situation. The use of the phenomenological approach in this study is intended to be able to describe symptoms or visible phenomena from the object of the research.

\section{Research Findings}

Towards the principal's visionary leadership

1. Creating a School Vision and Mission

The principal of SDIT Baitul Jannah did not create a school vision and mission, but carried out the vision of the Baitul Jannah foundation, making the vision and mission of the school based on the objectives of national education then the school still using the foundation's vision and mission, can be seen in figure 1 .

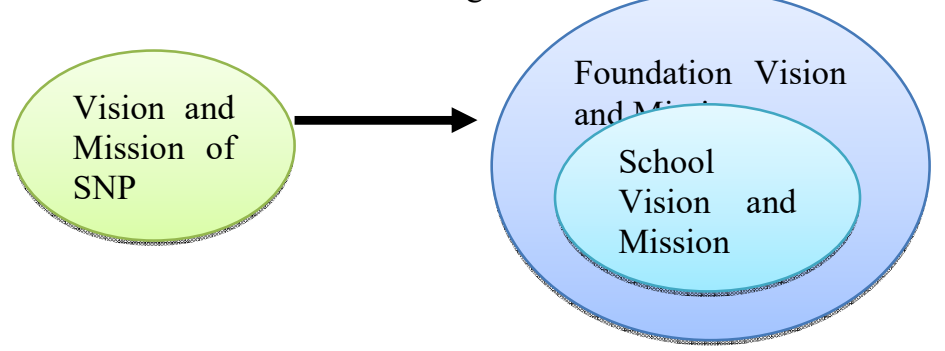

Figure 1. Context Diagram to Create Vision and Mission 


\section{Formulating School Vision and Mission}

The principal of SDIT Baitul Jannah did not formulate the school's vision and mission, because it still used the foundation's vision and mission, and the phenomenon at SDIT Baitul Jannah stated that the school principal in this period, October 2018, when the study took place the school was re-organized, the principal was installed on October 5, 2018, The study was conducted on October 10, 2018 so that the principal did not make the school's vision and mission, the process of formulating the mission of the SDIT Baitul Jannah foundation refers to the formulation of national education goals, can be seen in figure 4.9.

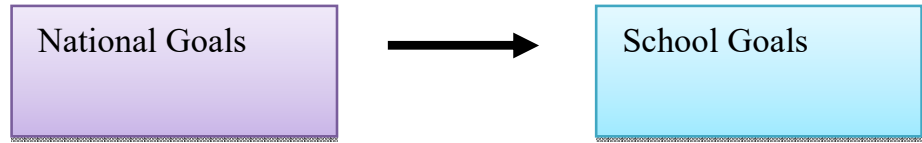

Figure 4.9 Context Diagram to Create Vision and Mission

3. Transformation of School Mission Vision

The principal explained that the foundation's vision and mission as the school's vision and mission in the new school year for all levels. Before arriving at the principal's school, together with school management, and the teacher making annual, semester, weekly and daily programs, then delivered to students through the meeting of The student's parents in their respective classes, can be seen in the picture.

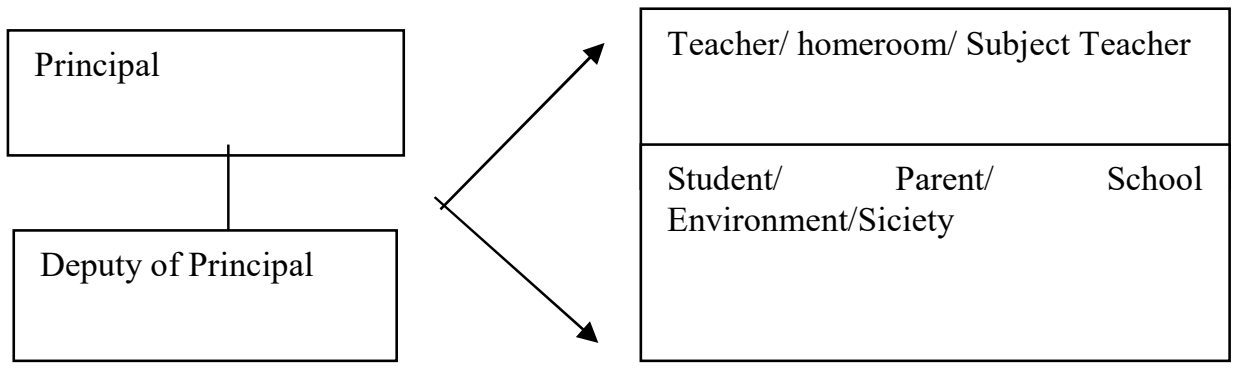

Picture: Context Diagram Transformation of School Mission Vision

4. Implementation of the School Vision and Mission

The results of the research exposure found that the principal carried out school activities referring to the foundation's vision and mission. The implementation of the school's vision and mission requires stages, namely the results of the foundation's vision and mission, together with the teacher and stageholder, the school principal plans or makes the annual, semester, weekly, and daily program activities, which is socialized during the new school year and then in every even semester is carried out in learning activities both daily and weekly. Transformational processes can be seen in the picture.

\begin{tabular}{|c|c|c|c|}
\hline $\begin{array}{ll}\text { Plan } & \text { The } \\
\text { Program } & \end{array}$ & $\begin{array}{l}\text { Implement The } \\
\text { program }\end{array}$ & $\begin{array}{ll}\text { Carry } & \text { Out } \\
\text { Supervision } & \end{array}$ & $\begin{array}{l}\text { Implement } \\
\text { School } \\
\text { Leadership }\end{array}$ \\
\hline
\end{tabular}

\section{Analysis}

Based on the exposure and research findings on the focus of the research of visionary leadership in the Integrated Islamic Elementary School principals, it was found that to get to the visionary leadership of the school principal, it was necessary to have steps:

1. Creating a school's vision and mission

The principal of SDIT Baitul Jannah did not create a vision and mission, but carried out the vision and mission of the foundation. However, it did not mean the principal was not visionary.

2. Formulating the school's vision and mission

The principal of SDIT Baitul Jannah did not formulate a vision and mission, because the principal immediately implemented the foundation's vision and mission.

3. Transforming the school's vision and mission

Then to parents, which is done during the new school year and even semester. The program is effective to remind the parents to be able to help achieve programs at school.

4. Implementation of the principal school's vision and mission

The principal of SDIT Baitul jannah can implement the vision and mission into an activity well, both the 
activities of teachers and students in order to maintain and improve the quality of education at SDIT Baitul Jannah.

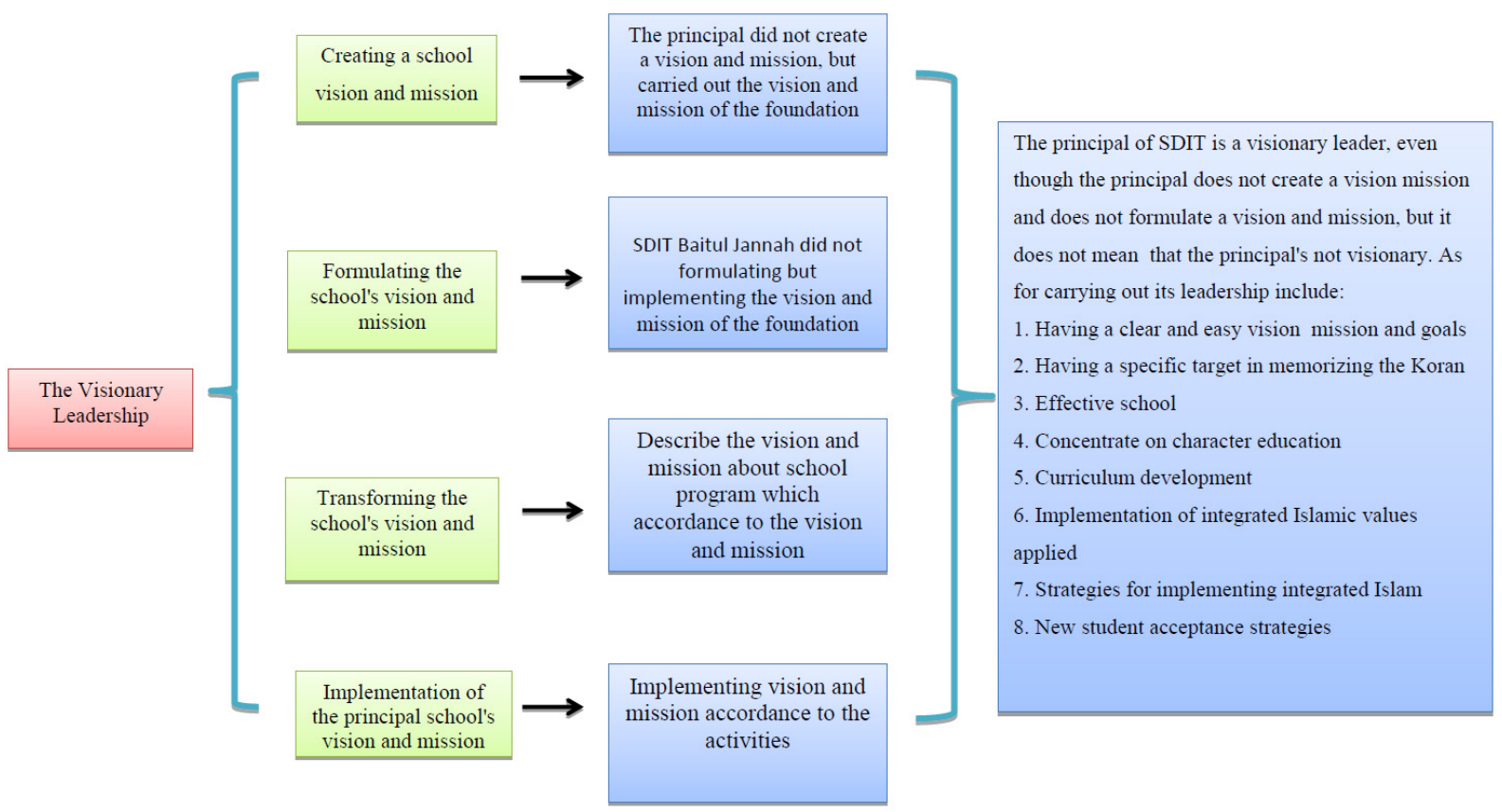

\section{Result}

The School Principals of SDIT are principals who have visionary leadership, to become visionary, school principals must have indicators including having: clear and realized vision, high integrity, implementation and initiative, strong spiritual values, courage in stepping, effective relationships, partnering with other people, insights into the future carry out self-development, strategic and systematic. If doing so, the SDIT principal and visionary leadership will achieve education which according to national goals and effective education with character. Clearly can be seen in figure

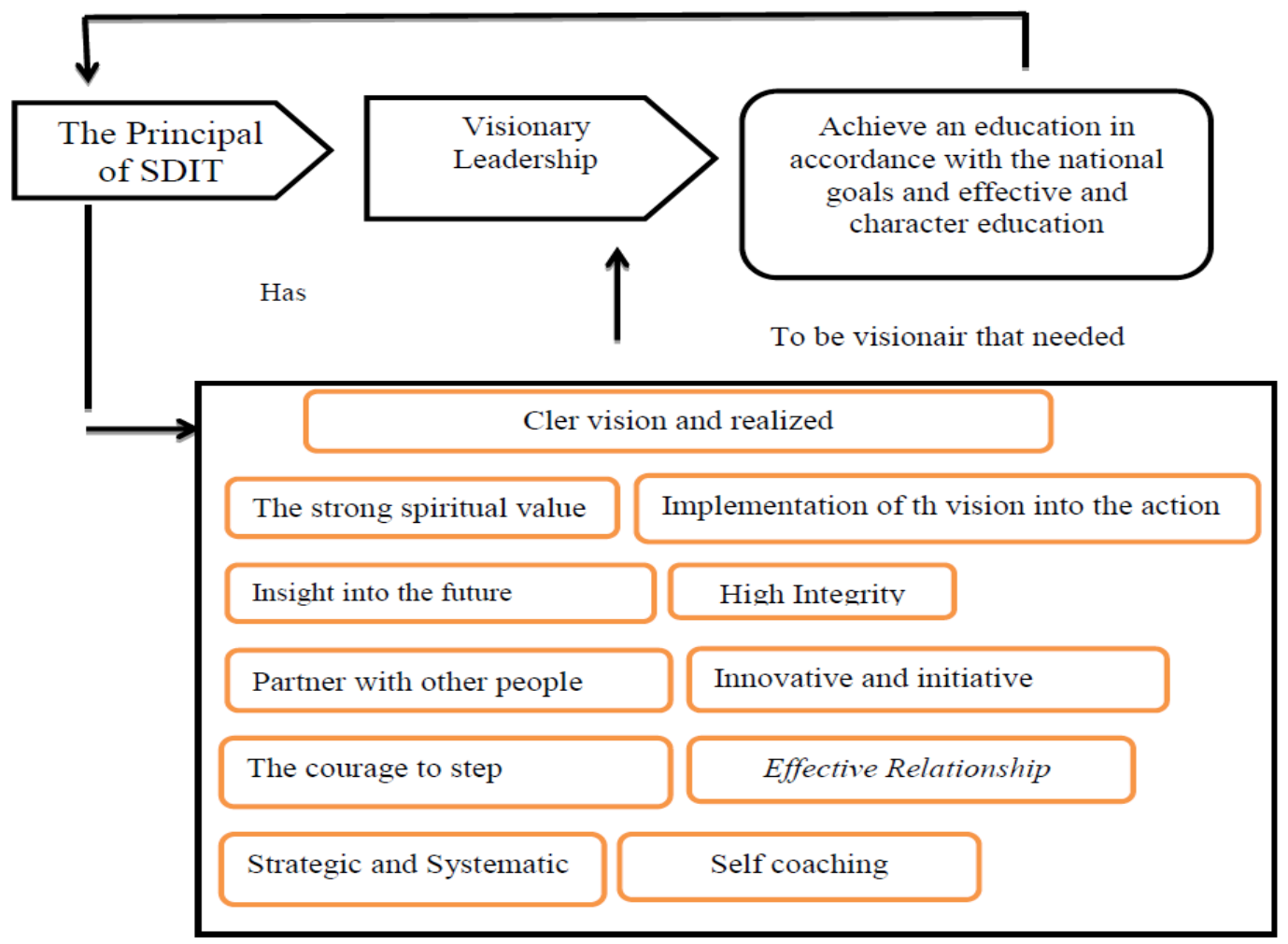

Figure: Visionair Leadership Hipotetic Integrated Islamic Primary School 


\section{Discussion}

Presentation of discussion is based on the process of observation, observing and exploring information on the SDIT Baitul Jannah, as follows:

\section{1) Creating a School Vision and Mission}

Creating a school vision and mission that principals create better aspirations for the future of the school is everyone's dream because everyone learns, as an effort to realize the ideals.

The principal of SDIT Baitul Jannah although still using the foundation's vision and mission as the school's vision and mission, the principal can develop the vision and mission in SDIT. The vision and mission in SDIT is in accordance with the theory, namely a short vision and mission that is easy to implement, easy to appreciate even though there are differences in creating a school vision and mission. The principal of SDIT Baitul Jannah did not make the school's vision and mission that carried out in school activities, a vision and mission which has done at the school activity is vision and mission of the foundation.

\section{Formulating the school's vision and mission}

The principal must formulate a clear and measurable vision of his leadership, and can be understood by all academic and non-academic staff so that they understand what must be done according to the principal's vision.

Formulating the school vision and mission accordance with the theory. Academic advancement of students, creating a very decent school atmosphere for education and learning, instilling leadership attitudes towards all academic and non-academic staff, enhancing learning, and managing all academic and non-academic staff to manage academic and non-academic services in order accelerate progress.

The formulation of SDIT Baitul Jannah's vision and mission is easy to implement, the principal of SDIT Baitul Jannah did not formulate a vision and mission.

\section{Transforming the school's vision and mission}

Transforming the vision and mission of the school that visionary leaders must be able to communicate, socialize, as well as collaborate with people to build, maintain, and develop their shared vision.

School transformation in two SDIT was already obsessed with theory. The principal has (1) the ability to explain the vision to others, (2) be able to express vision and (3) be able to expand the vision to a different leadership context. Schools have built effective communication so that the school's vision and mission is achieved. The implementation of the transformation of the vision and mission of the principal of SDIT Baitul Jannah at the time of welcoming new students, and at the time of the daily program, was explained in the connecting book and letter.

\section{Implementation of the school's vision and mission}

That describes and implements the implementation of the vision is the ability of the leader in describing and translating the vision into action.

The demands of memorizing the Quran are not only intended for students. Teachers also have programs to memorize and improve reading of the Qur'an, principals create the disciplinary of the teachers and students, create an Islamic environment, give facilities to students activities that are fun, cooperate with families indirectly formed communication with the connecting book.

To achieve character and effective school education, all activities are carried out in accordance with the school's vision and mission, visionary leaders have the ability of leaders to create, formulate, communicate, explain, socialize, transform, and implement ideal thoughts that come from themselves or as a result of interaction social among organizational members and stakeholders who are believed to be the ideals of the organization in the future that must be achieved or realized through the commitment of all personnel.

\section{Analysis}

Based on the exposure and research findings on the focus of the study, the visionary leadership of the integrated Islamic Elementary School principal was found that The principal of SDIT Baitul Jannah was a visionary school principal, with ideas that built in the school, so the school could develop better. Although the principal of the SDIT Baitul Jannah did not create a vision and mission and did not formulate a vision and mission, but it did not reduce the principal's visionary. As for carrying out its leadership have differences and similarities including:

1) Have a clear and easy vision and goals, 3) Have a specific target in memorizing the Qur'an, 4) Effective schools, 5) Concentration on character education. Differences: 1) Curriculum development, 2) Implementation of integrated Islamic values applied, 3) Strategies for implementing integrated Islam, 4) New student acceptance strategies. More details can be seen in the context diagram image.

\section{Conclusion}

SDIT Baitul Jannah does not create a vision and does not formulate a vision and mission, but it does not reduce the visionary of the principal. 2) Have a clear and easy vision and goals, 3) Have a specific target in memorizing Al Quran, 4) Effective schools, 5) Concentration on character education. Differences: 1) Curriculum development, 2) Implementation of integrated Islamic values applied, 3) Strategies for implementing integrated 
Islam, 4) New student acceptance strategies. More details can be seen in the context diagram image

\section{Daftar Pustaka}

Ani Kalayjian, DR. 12 Secrets of Visionary Leaders Meaningfulworlds.com - https://goo.gl/mfa4mA.

Bafadal, Ibrahim. 2016. Penilaian Kinerja Kepala Sekolah sebagai Pemimpin Pembelajaran dalam Rangka Peningkatan Akuntabilitas Sekolah. Manajemen Pendidikan, 25, 1-9.

Bhargavi, Swapna, \& Yaseen, Ali. 2016. Leadership styles and organizational performance. Strat Manage Q, 4(1), 87-117.

Erfan, Erfan, Arifin, Imron, \& Djatmika, Ery Tri.2017. Kepemimpinan Visioner Kepala Sekolah Dalam Pengimplementasian Pendidikan Budi Pekerti. Paper presented at the Seminar Nasional Mahasiswa Kerjasama Direktorat Jenderal Guru dan Tenaga Kependidikan Kemendikbud 2016.

Fitrah, Muh. 2017. Peran kepala sekolah dalam meningkatkan mutu pendidikan. Jurnal Penjaminan Mutu, 3(1), $31-42$.

Hariri, Hasan, Monypenny, Richard, \& Prideaux, Murray. (2014). Leadership styles and decision-making styles in an Indonesian school context. School Leadership \& Management, 34(3), 284-298.

Hidayah, Nurul. 2015. Kepemimpinan Visioner Kepala Sekolah. Dalam Meningkatkan Mutu Pendidikan. Yogyakarta: Ar-Ruzz Media.

Irwana, Ade. 2015. Jurnal Administrasi Pendidikan Kepemimpinan Visioner Kepala Sekolah Dan Kinerja Guru Terhadap Efektifitas Sekolah Di Sekolah Dasar

James, William. 2013. The principles of psychology: Read Books Ltd.

Karweti, Engkay. 2010. Pengaruh kemampuan manajerial kepala sekolah dan faktor yang mempengaruhi motivasi kerja terhadap kinerja guru SLB di Kabupaten Subang. Jurnal Penelitian PendidikanVol, 11, 77-89.

Mulyasa, E.2009. Menjadi Kepala Sekolah Profesional. Bandung: Rosda.

Mulyasa, H. E. 2012. Manajemen \& Kepimimpinan Kepala Sekolah. Jakarta: Bumi Aksara.

Moleong, L.J. 2011. Metodologi Penelitian Kualitatif Edisi Revisi. Bandung: PT Remaja Rosdakarya.

Nanus, Burt. 2001. Kepemimpinan Visioner. Alih Bahasa oleh Frederick Ruma. Jakarta: Prenhalindo

Nasir, Ibnu pada Juni 5, 2012. Kepemimpinan Pendidikan. http://www.aksibelajar.com/2012/kepemimpinan visioner. (diakses pada tanggal 5 Mei 2018, Pukul 07.30 WIB).

Nurwahid, Hidayat. Alaydrus Fahmy. 2015. Standar Mutu Sekolah Islam Terpadu. Jaringan Sekolah Islam Terpadu. Jakarta.

Robbins, Stephen. P. 2006. Prilaku organisasi. Edisi ke-10. Jakarta: PT Indeks

Sedarmayanti.2010. Manajemen Sumber Daya Manusia, Reformasi Birokrasi dan Manajemen Pegawai Negri Sipil. Bandung: PT RefikaAditama. 